\title{
Statyba
}

\section{METHOD OF PROJECT MULTICRITERIA DECISION SYNTHESIS ON THE BASIS OF DECISION SUCCESS CRITERION}

\author{
V. Šarka , E. K. Zavadskas \& L. Ustinovičius
}

To cite this article: V. Šarka , E. K. Zavadskas \& L. Ustinovičius (2000) METHOD OF PROJECT MULTICRITERIA DECISION SYNTHESIS ON THE BASIS OF DECISION SUCCESS CRITERION, Statyba, 6:3, 193-201, DOI: 10.1080/13921525.2000.10531586

To link to this article: https://doi.org/10.1080/13921525.2000.10531586

Published online: 26 Jul 2012.

Submit your article to this journal $\llbracket$

Џ Article views: 70

4 Citing articles: 1 View citing articles 준 


\title{
PROJEKTU DAUGIAKRITERINIŲ SPRENDIMŲ SINTEZĖS REMIANTIS PRIIMAMO SPRENDIMO SĖKMĖS KRITERIJUMI METODAS
}

\author{
V. Šarka, E. K. Zavadskas, L. Ustinovičius \\ Vilniaus Gedimino technikos universitetas
}

\section{1. !vadas}

Atliekant daugiakriterini projektavimą dažnai reikia priimti sprendimą analizuojant, sujungiant kelis uždavinius i visumą. Taip yra atliekama keliu tarpusavyje susijusių statybinių uždavinių sintezè, nagrinèjant šiuos pagrindinius klausimus:

- metodas turi būti patogus taikyti ir teikti tikslią bei aiškią informaciją apie galimą priimamą sprendimą;

- reikia sudaryti kaip galima daugiau variantų, kad rezultai būtų tikslesni;

- sintezé - ivairių uždavinių etapinių sprendimu jungimas i bendrą projektą, remiantis ryšio (alternatyvu suderinamumo) lentelèmis.

Minèti teiginiai yra tik dalis daugiakriteriniu sprendimų metodus apibūdinančių požymių. Siekiant ịvykdyti šiuos bei kitus daugiakriteriniams metodams keliamus reikalavimus [2], siūlomas daugiakriterinių sprendimų sintezès metodas (DSS1). Pirminè idèja bei panašaus daugiakriterinių sprendimų sintezès metodo algoritmas minimi [3]. Tačiau nagrinèjant siūlomą idèją metodo algoritmas buvo patobulintas - sukurtas naujas daugiakriteriniu sprendimu sintezès metodas (DSS1). Šis metodas yra pagrịstas priimamo sprendimo sèkmès (PSS 2) kriterijumi, tarpiniuose etapuose yra taikomi du papildomi metodai: artumo idealiajam taškui metodas, aprašytas [1, 4], bei absoliutaus artumo idealiajam taškui metodas (TOPSIS_A).

\section{Pagrindiniai DSS1 metodu sprendžiami klausimai}

DSS1 metodo esmè - keliu tarpusavyje susijusių techniniu sprendimų, kiekviename etape atrenkant tik po dvi pagal nutylèjimą (arba daugiau, tik metodo naudotojui papildomai nustačius) geriausias alternatyvas, sintezè. Kiekviename etapo pakopos sprendžiamame mazge paliekamų alternatyvų skaičius $m_{k}$ priklauso nuo nagrinèjamo uždavinio svarbumo lygio bei sprendimui pateikiamų alternatyvų skaičiaus, tačiau visais atvejais paliekamų alternatyvu skaičius $m_{k}>1$. Jeigu $m_{k}=1$, tai netikslinga itraukti ši procesą ar projektą i sintezès DSS 1 metodu sprendžiamą uždavini, kaip turinti vieninteli galimą sprendimo variantą. Jeigu $m_{k}>2$, tai neracionaliu alternatyvu atmetimas atliekamas pastebejus, kad, palikęs visas alternatyvas, galimas sprendimo eigoje, ir gavęs galutini rezultata, naudotojas gauna visą informacija apie geriausius sistemos siūlomus variantus. Taciau kartu jis atsiduria ir nepatogioje padètyje. Trumpai paaiškinsime kodèl. Atliekant sprendimą bet kuriuo daugiakriterinių sprendimu metodu, svarbiausia gautus rezultatus surūšiuoti pagal prioritetinę eilutę ir naudingumo laipsni. Naudotojui pateikiami pagal santykinio reikšmingumo kriterijus i prioritetinę eilutę išdèstyti visi galimi sprendimo variantai. Atrodytu viskas gerai, galima išsirinkti geriausią iš jų. Taciau, panagrinèję projektų sintezès kompromiso kompensaciniu modeliu SKK3 metodu gautą rezultatą [5] (7 lentelè), kur sprendimui buvo sudaryta 9900 galimu variantu, matome. kad 10-as pagal gerumą variantas nuo 1-ojo skiriasi tik per $1,05 \%$, todèl nesunkiai galima pastebèti, kad kuo daugiau bus nagrinèjamu pakopu, tuo daugiau bus galimu sprendimo variantų, ir šis skirtumas automatiškai mažès. O tai reiškia, kad iškyla problema, kaip prïmti efektyvų, visus tenkinanti sprendima, kai keli variantai pagal naudingumo laipsni yra labai arti vienas kito.

Dar vienas argumentas DSS1 metodo naudai buvo pastebètas nagrinejant tą pati pavyzdi. Pasirodo, SKK3 metodu sprendžiamame uždavinyje dalinių projektu alternatyvu santykiniai reikšmingumai yra labai skirtingai išsibarstę kiekvienos pakopos viduje. Tai lemia pakopos. turinčios mažiausią alternatyvų santykinio reikšmingumo kriteriju $\mathrm{K}_{\mathrm{bit}}$, išsibarstymą, alternatyvos išsidessto galutinèje sintezuojamų variantu prioritetų eilutèje viena šalia kitos iš eilès pagal vidinị šios pakopos alternatyvų prioritetų išsidèstymą. Taip galima gauti $1,2,3 \ldots \mathrm{m}$ vienas šalia kito esančius sintezuojamus variantus, kurie yra gauti viena po kitos keičiant tik vienos pakopos alter- 
natyvas. Toliau pasikeičia viena ar kelios kitų pakopu alternatyvos ir vèl gali pasikartoti tas pats veiksmas. Jeigu atidžiau peržiūrèsime SKK3 metodu gautus rezultatus [5], tai pastebèsime, kad iš penkių šiame uždavinyje nagrinèjamų pakopu trys, t. y. išorinių sienų, stogu bei langų siūlomos alternatyvos tarp pirmuju 10 turi tik po vieną alternatyva, ir tai yra nepatogu sprendimui priimti. Tai yra tiesiog tiksliai SKK3 metodu apskaiciuoti ir pateikti absoliučiai visi galimi variantai, išrikiuoti pagal santykini variantų tarpusavio reikšmingumo kriterijų $\mathrm{K}_{\text {bit }}$.

Dar vienas svarbus klausimas buvo išnagrinètas kuriant ši metoda. tai yra būtinybè kiekvienos pakopos viduje atliekant tarpinius sprendimus nustatyti statybos procesus ar projektus aprašančių alternatyvų absoliutų, o ne santykini reikšmingumą viena kitos atžvilgiu. Ši problema buvo pastebèta DSS1 metodui taikant priimamo sprendimo sèkmès (PSS 2) kriteriju $K_{3 s}$ ir atlikus šio metodo skaičiuojamuosius eksperimentus. Problemai spręsti buvo pritaikytas artumo idealiajam taškui metodas, îtraukiant i ši metodą kelis papildomus sprendimo elementus, patobulinant sprendimo algoritmą ir suteikiant metodui naują vardą - tai absoliutaus artumo idealiajam taškui metodas.

Autoriai siūlo naudotojui suteikti daugiau laisvés priimant sprendimą, t. y. suteikti galimybę kiekvienoje vykdomo sprendimo pakopoje sprendimo metu atsijoti neracionalius sprendinius, taip neitraukiant ju i galutinę sintezuojamų variantu prioritetu eilutę. Taigi naudotojui galutiniu sprendimu yra pateikiamas racionalus ir aiškus rezultatas - atsakymas į nagrinèjamą uždavinị, sudarytą iš kelių statybos procesų ar projektų.

\section{DSS1 metodo modelio struktūra}

Projektu sintezès sprendimas, remiantis priimamo sprendimo sèkmès (PSS 2) kriterijumi DSS 1 metodu, vykdomas 3 etapais, kurių kiekvienas dar skaidomas i smulkesnius veiksmus. I sprendimo etapas yra skirtas pradinių duomenų rinkimui ir duomenų bazès struktūros (DBS) pildymui. DSS 1 metodo II etapas skirtas tarpiniams sprendimams priimti. Čia yra nurodomas kiekvienos pakopos tolesniam sprendimui paliekamų alternatyvu skaičius ir atliekamas pradinès alternatyvu prioritetinès eilutès sudarymas, remiantis artumo idealiajam taškui metodo rezultatais. III etapas skirtas daugiakriterinei sprendimu sintezei ir galutinès sintezuojamy variantu prioritetinès eilutès sudarymui.
I sprendimo etapas. Atliekant sprendimą daugiakriterinių sprendimu sintezès metodais, iš nustatytos galimų variantų aibès reikia diskretiškai išrinkti efektyviausią variantą. Diskretinio išrinkimo uždavini pagal $[3,6]$ patogiausia spręsti matricos pavidalu. Surinkus informaciją apie kiekvieno sprendimo etapo nagrinèjamas alternatyvas, jas apibūdinančius kriterijus, jụ reikšmes ir pradinius reikšmingumus, kiekvienam etapui yra sudaromos sprendimu prièmimo matricos. Šalia šių matricų, kaip neatsiejama dalis, yra sudaromos ryšio lentelès, kurios nurodo kiekvieno etapo variantu tarpusavio ryši su bet kuriuo kito etapo variantu.

Visa ši sprendimui priimti reikalinga informacija yra surenkama, analizuojama, jungiama ir ivedama $i$ autoriu siūlomą duomenų bazès struktūrą ( 1 pav.). Čia reikètų pažymèti, kad ne visa sprendimui reikalingą informacija galima gauti elementaria skaitmenine forma iš nagrinèjamus statybos procesus ar projektus apibūdinančios surinktos medžiagos. Užpildžius pradinę duomenų bazę turimomis skaitinèmis reikšmèmis, likusią trūkstamą informaciją (projektus apibūdinančių rodikliụ pradiniai reikšmingumai, alternatyvas aprašančių kokybinių rodikliu reikšmės) reikia nustatyti naudojantis ekspertu paslaugomis bei gautą ekspertinę informaciją apdorojant specialiomis matematinemis priemonemis (ekspertiniai, porinio palyginimo, entropijos, žaidimu teorijos metodai).

DBS formavimas yra pirmas iš triju daugiakriterinių sprendimų sintezès metoduose išskiriamų etapų. Pirmasis šio etapo žingsnis yra uždavinio formulavimas ir sprendimo pakopu $k=\overline{1, c}$ formavimas. Kiekviena pakopa skirta vienai iš statybos procesus ar projektus apibūdinančiai duomenų lentelei, priklausančiai nagrinèjamam uždaviniui. Duomenų bazès struktūros sudarymo etapu yra atliekami šie veiksmai (2 pav.):

- Statybos procesų ir projektų sudètinių dalių, projektu sistemotechninio jivertinimo (PSI) duomenų lentelių šifrų sudarymas $k=\overline{1 . c}$ sprendimo pakopoms (lentelè A). PSl duomeny lentelès yra aprašomos statybos procesu arba projektų pavadinimais (pvz., $A_{1}$ - statybos vieta, $A_{2}$ - projektas, ..., $A_{k}$ - statybos rangovai, ..., $A_{c}$ - eksploatavimas).

- Statybos procesų ir projektų sudètinių dalių, apibūdinančių PSI duomenų lenteles, rodiklių grupių šifrų sudarymas $k=\overline{1, c}$ sprendimo pakopoms (lentele B), pvz., $B_{1}-$ statybos vieta. $B_{2}-$ projektas, ..., $B_{k}$ - statybos rangovai, .... $B_{c}$ - eksploatavimas. 


\begin{tabular}{|c|c|}
\hline \begin{tabular}{|c|l|} 
PSI duomenų lentelių šifrai \\
(lentelè A)
\end{tabular} \\
\hline \begin{tabular}{|c|l|} 
Lentelès \\
sifras
\end{tabular} & $\begin{array}{l}\text { Duomenų lenteles } \\
\text { pavadinimas }\end{array}$ \\
\hline $\mathrm{A}_{1}$ & Statybos vieta \\
\hline $\mathrm{A}_{2}$ & Projektas \\
\hline$\vdots$ & $\ldots$ \\
\hline $\mathrm{A}_{k}$ & Statybos rangovai \\
\hline$\vdots$ & $\ldots$ \\
\hline $\mathrm{A}_{\mathrm{c}}$ & Eksploatavimas \\
\hline
\end{tabular}

\begin{tabular}{|c|c|}
\hline \multicolumn{2}{|c|}{$\begin{array}{l}\text { Statybos procesụ ir projektụ sudètiniụ } \\
\text { dalių rodiklių lentelių šifrai (lentelé B) }\end{array}$} \\
\hline \begin{tabular}{|l} 
Lentelès \\
sifras
\end{tabular} & Rodikliu lentelès pavadinimas \\
\hline $\mathrm{B}_{1}$ & Statybos vieta \\
\hline $\mathrm{B}_{2}$ & Projektas \\
\hline$\vdots$ & $\ldots$ \\
\hline $\mathrm{B}_{\mathrm{k}}$ & Statybos rangovai \\
\hline$\vdots$ & $\ldots$ \\
\hline $\mathrm{B}_{\mathrm{c}}$ & Eksploatavimas \\
\hline
\end{tabular}

\begin{tabular}{|c|c|c|c|c|c|c|}
\hline \multicolumn{7}{|c|}{$\begin{array}{l}\text { Statybos procesu ir projektu sudetinių } \\
\text { dalių ryšio lentelių šifrai (matrica } R \text { ) }\end{array}$} \\
\hline \multirow{2}{*}{\begin{tabular}{|l} 
Lentelès \\
sifras
\end{tabular}} & \multicolumn{6}{|c|}{ Duomenu lentelès šifras } \\
\hline & $A_{1}$ & $A_{2}$ & $\ldots$ & $\mathrm{A}_{k}$ & $\ldots$ & $\overline{A_{c}}$ \\
\hline$A_{1}$ & - & $\mathbf{R}_{1,2}$ & .. & $\mathbf{R}_{1 . k}$ & $\because$ & $\mathbf{R}_{1, c}$ \\
\hline $\mathrm{A}_{2}$ & - & - & $\ldots$ & $R_{2, k}$ & $\cdots$ & $\mathrm{R}_{2, c}$ \\
\hline$\vdots$ & $\ldots$ & $\cdots$ & - & $\vdots$ & $\cdots$ & $\vdots$ \\
\hline$A_{k}$ & - & - & & - & $\ldots$ & $\underline{\mathbf{R}_{k, c}}$ \\
\hline 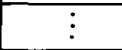 & $\ldots$ & $\ldots$ & $\ldots$ & $\ldots$ & - & $\vdots$ \\
\hline$A_{c}$ & - & - & $\ldots$ & - & $\ldots$ & - \\
\hline
\end{tabular}

Lenteles apibūdinanti rodiklių sistema (lentelẻ $\mathrm{B}_{\mathrm{k}}$ )

\begin{tabular}{|c|c|c|c|c|c|c|c|c|c|c|}
\hline \begin{tabular}{|c|} 
Rodikliu \\
lentelių \\
šifras
\end{tabular} & $\begin{array}{l}\text { Rodiklio } \\
\text { šifras }\end{array}$ & $\begin{array}{l}\text { Rodiklio } \\
\text { numeris }\end{array}$ & $\begin{array}{l}\text { Rodiklio } \\
\text { pavadi- } \\
\text { nimas }\end{array}$ & \begin{tabular}{|l|} 
Pinigine \\
ar nepi- \\
nigine \\
išraiška
\end{tabular} & $\begin{array}{l}\text { Matavi- } \\
\text { mo vie- } \\
\text { netai }\end{array}$ & $\begin{array}{l}\text { Minimi- } \\
\text { zuoti ar } \\
\text { maksi- } \\
\text { mizuoti }\end{array}$ & \begin{tabular}{|l|} 
Pradinis \\
reikš- \\
mingu- \\
mas
\end{tabular} & $\begin{array}{l}\text { Kokybi- } \\
\text { nis ar } \\
\text { kiekybi- } \\
\text { nis }\end{array}$ & $\begin{array}{l}\text { Minima- } \\
\text { lus pradi- } \\
\text { nis reikš- } \\
\text { min- } \\
\text { gumas }\end{array}$ & $\begin{array}{l}\text { Maksi- } \\
\text { malus } \\
\text { pradinis } \\
\text { reikšmin- } \\
\text { gumas }\end{array}$ \\
\hline $\mathrm{B}_{1}$ & $\operatorname{Rod}_{11}$ & $b_{\text {numl I }}$ & $\mathrm{b}_{\text {pavll }}$ & $\mathrm{b}_{\text {pin } 11}$ & $\mathrm{~b}_{\text {mat } 11}$ & $\mathrm{~b}_{\text {minnai }}$ & $\mathrm{b}_{\text {pradII }}$ & $\mathrm{b}_{\text {kokll }}$ & $b_{\min 11}$ & $\mathrm{~b}_{\max 11}$ \\
\hline $\mathrm{B}_{1}$ & $\operatorname{Rod}_{21}$ & $b_{\text {numl21 }}$ & $b_{\text {pav21 }}$ & $b_{\text {pin?1 }}$ & $b_{\text {mat } 21}$ & $b_{\text {mimu2 } 1}$ & $\mathrm{~b}_{\text {prad21 }}$ & $b_{\text {kok } 21}$ & $\mathrm{~b}_{\min 21}$ & $b_{\max 21}$ \\
\hline$\vdots$ & $\ldots$ & $\ldots$ & $\ldots$ & $\ldots$ & $\ldots$ & $\ldots$ & $\ldots$ & $\ldots$ & $\ldots$ & $\ldots$ \\
\hline $\mathrm{B}_{1}$ & $\operatorname{Rod}_{\mathrm{n} 1}$ & $\mathrm{~b}_{\text {nurm } \mathrm{nl}}$ & $\mathrm{b}_{\text {pavnl }}$ & $b_{\text {pin nl }}$ & $b_{\text {mat nl }}$ & $b_{\operatorname{miman} n}$ & $\mathrm{~b}_{\text {prad nl }}$ & $\mathrm{b}_{\text {kok nl }}$ & $\mathrm{b}_{\min \mathrm{nl}}$ & $b_{\max n I}$ \\
\hline $\mathrm{B}_{2}$ & $\operatorname{Rod}_{12}$ & $b_{\text {num } 12}$ & $\mathrm{~b}_{\mathrm{pav} 12}$ & $b_{\text {pin } 12}$ & $b_{\text {mall? }}$ & $b_{\text {mimal2 }}$ & $\mathrm{b}_{\text {prad12 }}$ & $\mathrm{b}_{\mathrm{kok} 12}$ & $\mathrm{~b}_{\min 12}$ & $b_{\max 12}$ \\
\hline $\mathrm{B}_{2}$ & $\operatorname{Rod}_{22}$ & $\mathrm{~b}_{\text {num } 22}$ & $\mathrm{~b}_{\mathrm{pav} 22}$ & $\mathrm{~b}_{\operatorname{pin} 22}$ & $\mathrm{~b}_{\text {mal } 22}$ & $\mathrm{~b}_{\text {mima22 }}$ & $b_{\text {prad2 }}$ & $\mathrm{b}_{\text {kok22 }}$ & $\mathrm{b}_{\min 22}$ & $b_{\max 22}$ \\
\hline$\vdots$ & $\ldots$ & $\ldots$ & $\ldots$ & $\ldots$ & $\ldots$ & $\ldots$ & $\ldots$ & $\ldots$ & $\ldots$ & $\ldots$ \\
\hline $\mathrm{B}_{2}$ & $\operatorname{Rod}_{n 2}$ & $b_{\text {num n } 2}$ & $b_{\text {pav n? }}$ & $\mathrm{b}_{\text {pin } \mathrm{n} 2}$ & $b_{\text {mat n2 }}$ & $b_{\operatorname{miman}} \mathbf{2}$ & $b_{\text {prad n? }}$ & $b_{\text {kok n? }}$ ? & $b_{\min n 2}$ & $b_{\max n^{2}}$ \\
\hline $\mathrm{B}_{\mathrm{c}}$ & $\operatorname{Rod}_{1 \mathrm{c}}$ & $b_{\text {num Ic }}$ & $\mathrm{b}_{\text {pav Ic }}$ & $b_{\text {pin Ic }}$ & $b_{\text {mat } k c}$ & $b_{\text {mima } 1 \mathrm{c}}$ & $\mathrm{b}_{\text {prad Ic }}$ & $\mathrm{b}_{\text {kok } \mathrm{kc}}$ & $b_{\min 1} c$ & $\mathrm{~b}_{\max 1 \mathrm{c}}$ \\
\hline$B_{c}$ & $\operatorname{Rod}_{2 \mathrm{c}}$ & $\mathrm{b}_{\text {num } 2 c}$ & $\mathrm{~b}_{\mathrm{pav} 2 \mathrm{c}}$ & $b_{\text {pin } 2 c}$ & $\mathrm{~b}_{\text {mat } 2 \mathrm{c}}$ & $\mathrm{b}_{\text {mima }} 2 \mathrm{c}$ & $b_{\text {prad 2c }}$ & $\mathrm{b}_{\text {kok } 2 \mathrm{c}}$ & $b_{\min 2} c$ & $\mathrm{~b}_{\max 2 \mathrm{c}}$ \\
\hline$\vdots$ & $\ldots$ & $\ldots$ & $\ldots$ & $\ldots$ & $\ldots$ & $\ldots$ & $\ldots$ & $\ldots$ & $\ldots$ & $\ldots$ \\
\hline
\end{tabular}

Duomenu lenteles sudarančiu alternatyvu sistema (lentelè $V_{k}$ )

\begin{tabular}{|c|c|c|c|c|}
\hline $\begin{array}{l}\text { Duomeny } \\
\text { lentelès } \\
\text { šifras }\end{array}$ & $\begin{array}{l}\text { Alterna- } \\
\text { tyvos } \\
\text { šifras } \\
\end{array}$ & $\begin{array}{l}\text { Alternatyvos } \\
\text { pavadinimas }\end{array}$ & $\begin{array}{l}\text { Alternatyvos } \\
\text { trumpas ap- } \\
\text { rašymas }\end{array}$ & $\begin{array}{l}\text { Grafinio } \\
\text { vaizdo nuo- } \\
\text { roda i diska } \\
\end{array}$ \\
\hline$A_{1}$ & $\operatorname{Var}_{11}$ & $\mathrm{v}_{\text {pavll }}$ & $\mathrm{v}_{\text {aprl11 }}$ & $\mathrm{v}_{\text {grall }}$ \\
\hline$\overline{A_{1}}$ & $\mathrm{Var}_{21}$ & $\mathrm{v}_{\text {pav21 }}$ & $\mathrm{v}_{\text {apr21 }}$ & $\mathrm{v}_{\mathrm{yra} 2 \mathrm{I}}$ \\
\hline$\vdots$ & $\vdots$ & $\ldots$ & $\ldots$ & $\ldots$ \\
\hline$\overline{A_{1}}$ & $\operatorname{Var}_{\mathrm{nl}}$ & $\mathrm{v}_{\text {pav } \mathrm{ml}}$ & $\mathrm{v}_{\mathrm{apr} \mathrm{ml}}$ & $\mathrm{V}_{\text {gra ml }}$ \\
\hline$A_{2}$ & $\operatorname{Var}_{12}$ & $\mathrm{v}_{\text {pav12 }}$ & $\mathrm{v}_{\text {apr12 }}$ & $\mathrm{v}_{\mathrm{gra} / 2}$ \\
\hline $\mathrm{A}_{2}$ & $\operatorname{Var}_{22}$ & $\mathrm{v}_{\text {pav2? }}$ & $\mathrm{v}_{\mathrm{apr} 22}$ & $\mathrm{v}_{\mathrm{gra} 22}$ \\
\hline$\vdots$ & $\vdots$ & $\ldots$ & $\ldots$ & $\ldots$ \\
\hline$A_{2}$ & $\operatorname{Var}_{\mathrm{m} 2}$ & $\mathrm{v}_{\text {pav m? }}$ & $\mathrm{v}_{\mathrm{apr} \mathrm{m}} \mathrm{z}$ & $\mathrm{v}_{\text {grai mI }}$ \\
\hline
\end{tabular}

\begin{tabular}{|c|c|c|c|c|}
\hline$\overline{A_{c}}$ & $\operatorname{Var}_{\mathrm{Ic}}$ & $v_{\text {paylc }}$ & $\mathrm{V}_{\mathrm{apr}} \mathrm{lc}$ & $\mathrm{v}_{\text {gralc }}$ \\
\hline$A_{c}$ & $\operatorname{Var}_{2 c}$ & $v_{\text {pay } 2 c}$ & $\mathrm{~V}_{\text {apric }}$ & $\mathrm{v}_{\text {arialec }}$ \\
\hline$\vdots$ & $\vdots$ & $\ldots$ & $\ldots$ & $\ldots$ \\
\hline $\mathrm{A}_{\mathrm{c}}$ & $\mathrm{Var}_{\mathrm{mc}}$ & $\mathrm{V}_{\mathrm{par} \mathrm{mc}}$ & $\mathrm{V}_{\mathrm{apr} \mathrm{ms}}$ & $\mathrm{V}_{\text {gra } \mathrm{mc}}$ \\
\hline
\end{tabular}

1 pav. Statybos procesų ir projektu sprendimo daugiakriterinių sprendimų sintezès metodais pradinių duomenų bazès struktūros (DBS) bendra schema

Fig 1. Primary database scheme for construction processes and project selection 

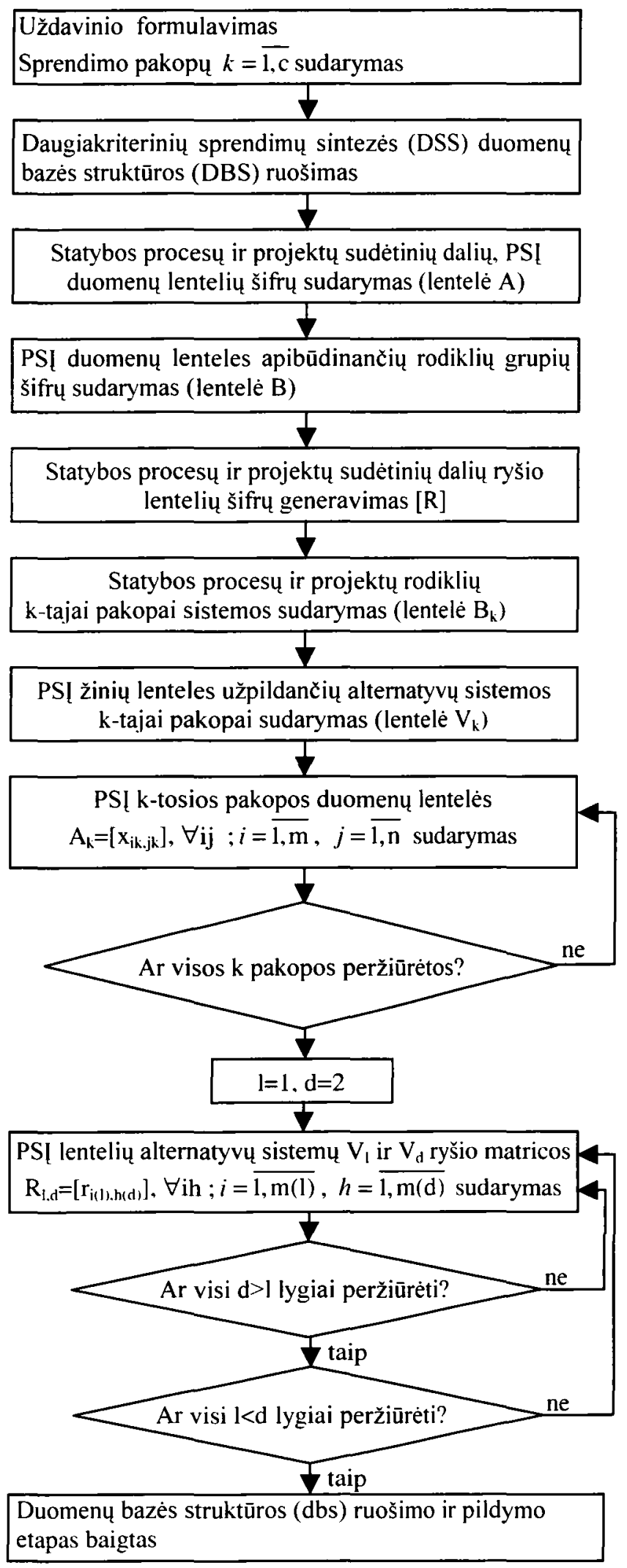

2 pav. Duomenų bazés struktūros kūrimo blokinè schema

Fig 2. Database structure creating block-scheme
- Statybos procesu ir projekty sudètinių dalių ryšio lenteliu šifrų generavimas (matrica [R]). Sudaromi ryšio lentelių tarp atskirų sprendimo pakopu sifrai, pvz., 1 pakopos $A_{I}$ - statybos vieta, ryšio lenteliu šifrai su kitomis pakopomis, tai: $r_{12}$ su $A_{2}$ - projektas, $r_{l k}$ su $A_{k}-$ statybos rangovai. $r_{l c}$ su $A_{c}$ - eksploatavimas.

- Statybos procesy ir projektu sudètines dalis aprašančiu rodiklių k-tajai pakopai sistemos sudarymas (lentelè $B_{k}$ ). Rodiklius aprašančią sistemą sudaro (skliausteliuose $\mathrm{I}$ rodiklio pavyzdinis ivedimas): $b_{\text {num II }}$ - rodiklio numeris (1): $b_{\text {parl } 1}$ - rodiklio pavadinimas (projekto kaina); $b_{\text {pin11 }}$ - rodiklis, išreikštas pinigine ar nepinigine išraiška $(\$)$; $b_{\text {mat11 }}$ - rodiklị apibūdinantys matavimo vienetai (tūkstančiais Lt); $b_{\text {mimat } 1}$ - požymis. Rodiklis yra laikomas minimizuojamu, kai mažesnè reikšmė yra geresnè, ir maksimizuojamu, kai didesnè reikšmè yra geresnè. Atsižvelgiant dalyvaujančių priimant sprendimą suinteresuotu grupių siekiamus tikslus, tas pats rodiklis gali būti ir minimizuojamas, ir maksimizuojamas

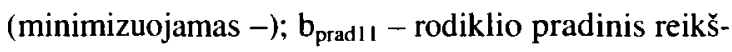
mingumas. Užpildžius ekspertines formas, apskaičiuojamas ekspertiniais metodais arba paimamas iš analogiškų projektų duomenų bazių (apskaičiuotas $0,58)$; $b_{\text {kokll }}$ - požymis, žymintis, ar rodiklis yra kiekybinis (tūkstančiai, metai, decibelai, kilovatai ir kt.), ar kokybinis - balai (kiekybinis); $b_{\min 1 \mathrm{l}}$ - rodiklio minimalus pradinis reikšmingumas suteikia galimybę nustatyti žemiausia pradinio reikšmingumo ribą ivedant rodikli $(0,1) ; b_{\max l 1}$ - rodiklio maksimalus pradinis reikšmingumas suteikia galimybę nustatyti aukščiausią pradinio reikšmingumo ribą ivedant rodikli (10). Paskutiniais dviem požymiais siekiama apsidrausti nuo galimų klaidingu, per dideliu pradinio reikšmingumo reikšmių ivedimo.

- PSI duomenų lenteles užpildančiu alternatyvụ sistemos k-tajai pakopai sudarymas (lentelè $V_{k}$ ). Alternatyvas aprašančią sistemą sudaro (skliausteliuose 1 alternatyvos pavyzdinis ivedimas): $v_{\text {pavil }}$ - alternatyvos pavadinimas (projektas 1 ); $v_{\text {apr } 11}$ - trumpas aternatyvos aprašymas (pagal užsakovo pateiktas technines sąlygas suprojektuotas 6 aukštu 312 darbo vietú administracinis pastatas. stačiakampio formos. G/b karkaso, „Reynobond“ sieniniais paneliais); $\mathrm{v}_{\text {grall }}$ - nuoroda $\mathrm{i}$ failą, kuriame grafiskai pa- 
vaizduota

nagrinèjama

alternatyva

(c: \metodai ADMINGProj1.JPG). Rekomenduojami JPEG, JPG grafiniai formatai. kaip esantys pakankamo tikslumo minimalaus dydžio.

- PSI k-tosios pakopos pagal rodikliụ sistemą $B_{k}$ duomenu lentelés $\mathrm{A}_{\mathrm{k}}=\left[\mathrm{x}_{\mathrm{ik} . \mathrm{j} \mathrm{k}}\right], \forall \mathrm{ij} ; i=\overline{1, \mathrm{~m}}, j=\overline{1, \mathrm{n}}$ sudarymas. Ji yra sudaroma matricos pavidalo, pakopą sudarančias alternatyvas išdèstant eilutejje, o alternatyvas aprašančius rodiklius - stulpeliuose $\left(A_{1}, A_{2}, \ldots . A_{c}\right)$ (1 lentelè).

1 lentelè. PSI k-tojo etapo duomenu lentelè $A_{c}$.

Table 1. Primary data table of comparable variants

\begin{tabular}{|c|c|c|c|c|c|c|}
\hline \multirow{2}{*}{$\begin{array}{l}\text { Alternatyvos } \\
\text { numeris }\end{array}$} & \multicolumn{6}{|c|}{ Projekto sudètiniu dalių rodikliai } \\
\hline & $\operatorname{Rod}_{1 \mathrm{c}}$ & $\operatorname{Rod}_{2 \mathrm{c}}$ & $\cdots$ & $\operatorname{Rod}_{\mathrm{jc}}$ & $\cdots$ & $\operatorname{Rod}_{n c}$ \\
\hline $\mathrm{Var}_{1 \mathrm{c}}$ & $\mathbf{x}_{1 \mathrm{c}, 1 \mathrm{c}}$ & $\mathbf{x}_{1 \mathrm{c} .2 \mathrm{c}}$ & & $\mathbf{x}_{1 \mathrm{c} . \mathrm{j} \mathrm{k}}$ & $\ldots$ & $\mathbf{x}_{1 \mathrm{c}, \mathrm{nc}}$ \\
\hline $\mathrm{Var}_{2 \mathrm{c}}$ & $\mathbf{x}_{2 c .1 c}$ & $\mathbf{x}_{2 c .2 c}$ & $\cdots$ & $\mathbf{x}_{2 \mathrm{c} . \mathrm{j} \mathrm{c}}$ & $\cdots$ & $\mathbf{x}_{2 \mathrm{z} . \mathrm{nc}}$ \\
\hline$\vdots$ & : & $\vdots$ & & $\vdots$ & & $\vdots$ \\
\hline $\operatorname{Var}_{i c}$ & $\mathbf{x}_{\mathrm{ic} . \mathrm{lc}}$ & $\mathbf{x}_{\mathrm{ic}, 2 \mathrm{ci}}$ & & $\mathbf{x}_{\mathrm{ic} . \mathrm{jc}}$ & 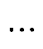 & $\mathbf{x}_{\mathrm{ic}, \mathrm{nc}}$ \\
\hline$\vdots$ & $\vdots$ & $\vdots$ & & $\vdots$ & & $\vdots$ \\
\hline $\mathrm{Var}_{\mathrm{mc}}$ & $\mathbf{x}_{\mathrm{mc} . \mathrm{lc}}$ & $\mathbf{x}_{\mathrm{mx} .2 \mathrm{c}}$ & & & 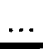 & $\mathbf{x}_{\mathrm{mc} . \mathrm{nc}}$ \\
\hline
\end{tabular}

- PSI lentelių variantu sistemų $V_{1}$ ir $V_{d}$ ryšio matricos $\mathrm{R}_{\mathrm{l}, \mathrm{d}}=\left[\mathrm{r}_{\mathrm{i}(\mathrm{l}), \mathrm{h}(\mathrm{d})}\right], \forall \mathrm{ih} ; i=\overline{\mathrm{l}, \mathrm{m}(\mathrm{l})}, h=\overline{1, \mathrm{~m}(\mathrm{~d})}, \mathrm{i} \neq \mathrm{h}$ sudarymas. Šis veiksmas yra skirtas suformuoti tarpusavio ryšiams tarp visų uždavinio sprendimo procese dalyvaujančiu atskiru procesu arba projektu alternatyvų. Čia galima atmesti nesuderinamas skirtingų sprendimo pakopu alternatyvas, atsisakyti nepageidaujamo, negalimo atskiru konstrukcijų derinio arba atsižvelgti i konkurse dalyvaujančiu firmy teikiamus apribojimus ju siūlomai produkcijai. Pavyzdžiui, irengiant monolitinio karkaso konstrukcija. netinka rangovo siūlomas atlikimo terminas, po kolonomis neekonomiška įrengti juostinius pamatus. Ryšio lentelès pavyzdys pateiktas 2 lentelèje.

2 lentelè. Ryšio tarp II ir c-tojo etapų $\left(R_{2 . c}\right)$ lentelè

Table 2. Relation table structure, for comparative variants

\begin{tabular}{|c|c|c|c|c|}
\hline \multirow{2}{*}{$\begin{array}{l}\text { II etapo alter- } \\
\text { natyvos }\end{array}$} & \multicolumn{4}{|c|}{ c-tojo etapo altematyvos } \\
\hline & $\operatorname{Var}_{1(c)}$ & $\operatorname{Var}_{2(c)}$ & \begin{tabular}{|l|l|l|}
$\ldots$ & $\operatorname{Var}_{\mathrm{i}(\mathrm{c})}$ \\
\end{tabular} & \begin{tabular}{|l|l|l|}
$\ldots a r_{m(c)}$ \\
\end{tabular} \\
\hline $\operatorname{Var}_{1(2)}$ & $\mathrm{r}_{12, \mathrm{k}}$ & $r_{12.20}$ & $\ldots r_{12, \mathrm{ic}}$ & $\ldots r_{12, \mathrm{nk}}$ \\
\hline $\operatorname{Var}_{2(2)}$ & $r_{22.1 \mathrm{c}}$ & $r_{22,2 x}$ & $\ldots r_{22, i c}$ & $\ldots r_{22, m x}$ \\
\hline : & $\vdots$ & $\vdots$ & $\vdots$ & $\vdots$ \\
\hline $\operatorname{Var}_{i(2)}$ & $r_{i 2, j c}$ & $r_{i 2.2 x}$ & $\ldots \mathrm{r}_{\mathrm{i} 2, \mathrm{ic}}$ & $\ldots \mathrm{r}_{\mathrm{i}, \mathrm{mc}}$ \\
\hline : & $\vdots$ & & $\vdots$ & $\vdots$ \\
\hline $\operatorname{Var}_{\mathrm{m} \mid 21}$ & $\mathrm{r}_{\mathrm{m} 2.1 \mathrm{c}}$ & $r_{m 2 . .2}$ & $\ldots r_{m}^{2} \cdot i c$ & $\ldots r_{m 2, m k}$ \\
\hline
\end{tabular}

Atlikus visus išnagrinètus veiksmus, daugiakriterinių sprendimų sintezès (DSS) duomenų bazès struktūros (DBS) ruošimo ir pildymo etapas baigiamas.

II sprendimo etapas ( 3 pav.) skirtas apdoroti tam tikrus statybos procesus arba projektus apibūdinančias duomenų lenteles (1lentelè) ir paruošti jas tolesniam sprendimui. Sprendimas vykdomas pakopomis. Tarkime, vykdome sprendimą k-tajai sprendimo pakopai $k=1$. c ; čia c yra sprendimo pakopų (duomenų lentelių) skaicius. Kiekviena pakopa atspindi sistemos veiksmus su viena šiai pakopai skirta pagrindine duomenų lentele $\left(A_{k}\right)$ bei pagalbinèmis lentelèmis, tokiomis kaip ekspertinio ivertinimo, porinio palyginimo. Šių metodų aprašymą galima rasti $[1,3]$ literatūroje.

II sprendimo etapas susideda iš šių veiksmų, tai:

- PSI k-tosios pakopos pradinių duomenu peržiūrèjimas ir sprendimu prièmimo matricos $[P]$, remiantis PSI duomenų lentele $A_{k}$, sudarymas.

- Rodiklių pradinio reikšmingumo k-tajai pakopai nustatymas. Pradiniams rodiklių reikšmingumams nustatyti siūloma taikyti ekspertinị arba porinio palyginimo pradinio reikšmingumo nustatymo metodus.

- Alternatyvu santykinio reikšmingumo kriteriju $K_{\text {bi }}$ eile $\mathrm{k}$-tajai pakopai nustatoma artumo idealiajam taškui metodu. Norint bendram darbui sujungti tik mazge $g_{k . e}$ paliekamų $m_{k}$ geriausių alternatyvu skaičių, reikia sudaryti pagal santykinio reikšmingumo kriterijus $\mathrm{K}_{\text {bit }}$ nustatytą pradinę alternatyvu prioritetu eilutę.

- Pradinès prioritetu eilutès k-tajai pakopai remiantis alternatyvų santykinio reikšmingumo $\mathrm{K}_{\text {bit }}$ kriterijais sudarymas. Sudaroma santykinè alternatyvų prioritetiškumo eilè k-tajai pakopai:

$$
\left\{a_{k}\right\}=\left\{a_{5} \succ a_{2} \succ a_{m} \succ \ldots \succ a_{i} \succ \ldots \succ a_{7}\right\} .
$$

Sudarius santykines alternatyvu prioritetiškumo eilutes visoms $k=\overline{1, c}$ pakopoms, c yra sprendimo pakopu skaičius, ir II etapo darbas yra baigiamas.

III sprendimo etapas. Vykdoma daugiakriterinè variantų sintezè. Sprendimas taip pat vykdomas pakopomis. Kaip papildomas sprendimo elementas, kiekviena $\mathrm{k}$ pakopa yra sudaroma iš tam tikro skaičiaus $z_{k}$ mazgų. Kiekviename šio etapo $k$-tosios pakopos sprendžiamame $\mathrm{z}_{\mathrm{k}}$ mazge yra paliekamas naudotojo nustatytas $m_{k}$ alternatyvu skaičius, tačiau, kaip jau buvo mineta, $m_{k}>1$ ir $m_{k} \leq m$. Vykdant sprendimą k-tosios pakopos mazguose, sistema, 
PSI k-tosios pakopos pradiniai duomenys Sprendimų prièmimo matricos $\mathbf{P}$ sudarymas

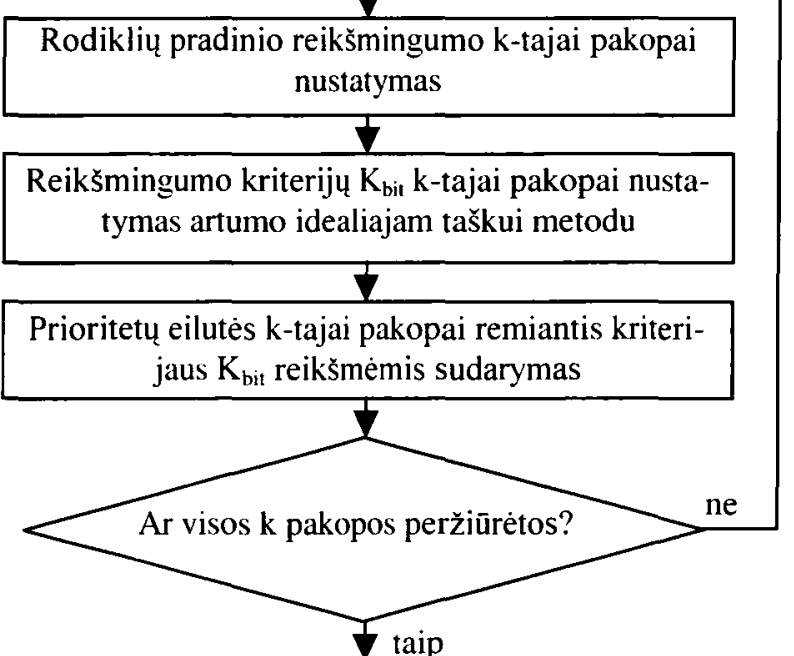

Sprendimų medžio (SM) k-tosios pakopos mazgo $\mathrm{g}_{\mathrm{k} . \mathrm{e}}, \forall \mathrm{ke} ; k=\overline{1, \mathrm{C}} e=\overline{1, \mathrm{z}_{\mathrm{k}}}$ formavimas

$\frac{1}{\text { SM k-tosios pakopos mazgo } g_{k . e}, m_{k} \text { geriausiu al- }}$ ternatyvu, remiantis ryšių matrica $R_{\mathrm{l} . \mathrm{d}}$, sudarymas

SM k-tosios pakopos mazge $\mathrm{g}_{\mathrm{k} . \mathrm{e}}$ paliktu geriausiu alternatyvų absoliučių reikšmingumo kriterijų $\mathrm{K}_{\text {bira }}$ reikšmių nustatymas

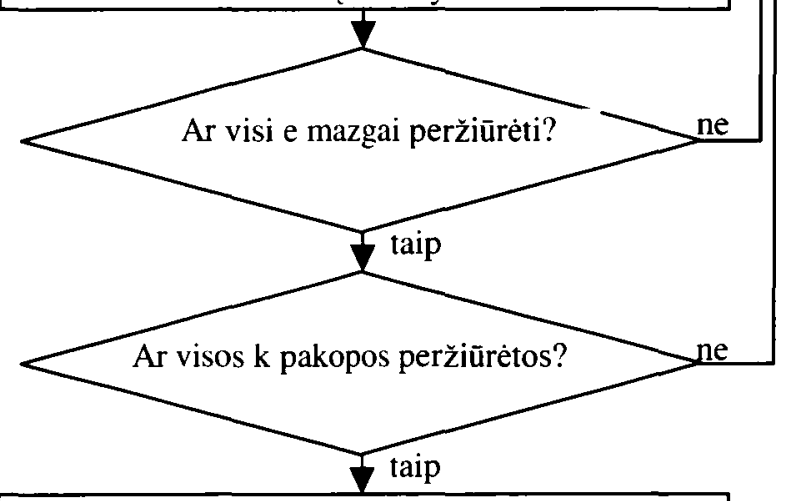

Galutinés daugiakriteriniu sprendimų matricos [W] remiantis SM formavimas DSS 1 metodu

Kiekvienai sprendimų šakai s priimamo sprendimo sèkmès (PSS 2) kriterijaus $K_{3, s}$ nustatymas

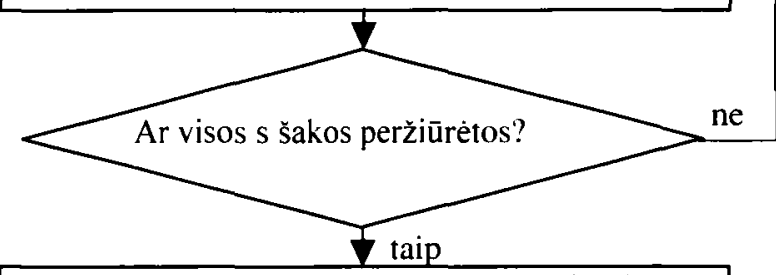

Lyginamų s variantu prioritetiškumo eilès $\left\{w_{s}\right\}$, remiantis (PSS 2) kriterijumi $\mathrm{K}_{3,}$, sudarymas

3 pav. Projektų sintezes DSSI metodo blokinè schema

Fig 3. Block-scheme of the multicriteria project synthesis method DSS 1 remdamasi ryšių matricu $R_{l . d}$ (2 lentelè) ir anksčiau sprendimo metu nagrinètu pakopu nuo 1 iki k-1 duomenimis bei sprendimo metu k-tojoje pakopoje paliekamu $m_{k}$ alternatyvu, atlieka visų galimų k-tojoje pakopoje palikti alternatyvų analizę ir išrenka racionaliausias $m_{k}$ alternatyvas tolesniam sprendimui. Kartu atliekama paliekamų alternatyvų sinteze ir yra sudaromas sprendimu medis (SM) (4 pav.) taip gaunant s galimu sprendimo variantu. Galutineje sprendimo stadijoje suformuojami $\mathrm{SM}$ variantai $w_{\mathrm{s}}, s=\overline{1, \mathrm{z}_{\mathrm{c}}}$, yra nustatomos gautu variantu priimamo sprendimo sèkmès (PSS 2) [1] kriterijų $\mathrm{K}_{3 \mathrm{~s}}$ reikšmès. Remiantis kriterijaus $\mathrm{K}_{3 \mathrm{~s}}$ reikšmémis, sintezuojami variantai yra išrikiuojami i prioritetinę eilutę. Toliau detaliau bus apžvelgiami šiame etape vykdomų veiksmų ypatumai:

- Sprendimų medžio (SM) k-tosios pakopos $g_{k . e}$ mazgo formavimas; ciia $z_{k}$ yra $k$-tosios pakopos mazgu skaičius, nustatomas pagal formulę (1):

$$
z_{\mathrm{k}}=\left(\mathrm{z}_{\mathrm{k}-\mathrm{l}} * \mathrm{~m}_{\mathrm{k}}\right) ; \forall \mathrm{k}, k=\overline{2, c}, z_{1}=m_{\mathrm{l}} \text {. }
$$

Bendras sprendime dalyvaujančių sudaromų mazgų skaičius z nustatomas pagal formulę (2):

$$
z=\sum_{k=1}^{c} z_{k} \text {. }
$$

- SM k-tosios pakopos $\mathrm{g}_{\text {k.e }}$ mazgo variantu, išrinktų iš nurodyto kiekio nagrinejjamos k-tosios pakopos $m_{k}$ geriausių alternatyvu, remiantis ryšiụ matrica $\mathrm{R}_{\mathrm{f} . \mathrm{d}}$, sudarymas. Čia vyksta dvieju arba daugiau naudotojo nurodytu geriausiu alternatyvu atranka. Ji vykdoma iš i alternatyvu $i=\overline{\mathrm{l}, \mathrm{m}}$; čia $\mathrm{m}$ yra k-tosios pakopos alternatyvu skaičius pagal $\mathrm{j}$ šias alternatyvas apibūdinančiu kriteriju $j=\overline{1, n}$; čia n yra ktosios pakopos alternatyvas apibūdinačiu kriteriju skaičius.

- SM k-tosios pakopos g $_{\text {.e }}$ mazge paliktu geriausių alternatyvu absoliučių reikšmingumo kriteriju $\mathrm{K}_{\text {bita }}$ nustatymas, remiantis autorių siūlomu absoliutaus artumo idealiajam taškui metodu. Panagrinèjus kelis daugiakriteriniu sprendimų metodus $[1,2,3]$ ir šiais metodais išspręstụ uždavinių rezultatus, paaiškèjo, kad gaunami rezultatai yra santykiniai, t. y. alternatyvu prioritetines eilutes lemiantys ivairiausiais metodais gaunami šių alternatyvų reikšmingumai yra santykiniai, apibrèžiantys ir leidžiantys nustatyti tik nagrinejjamų alternatyvų vietą viena kitos atžvilgiu. 


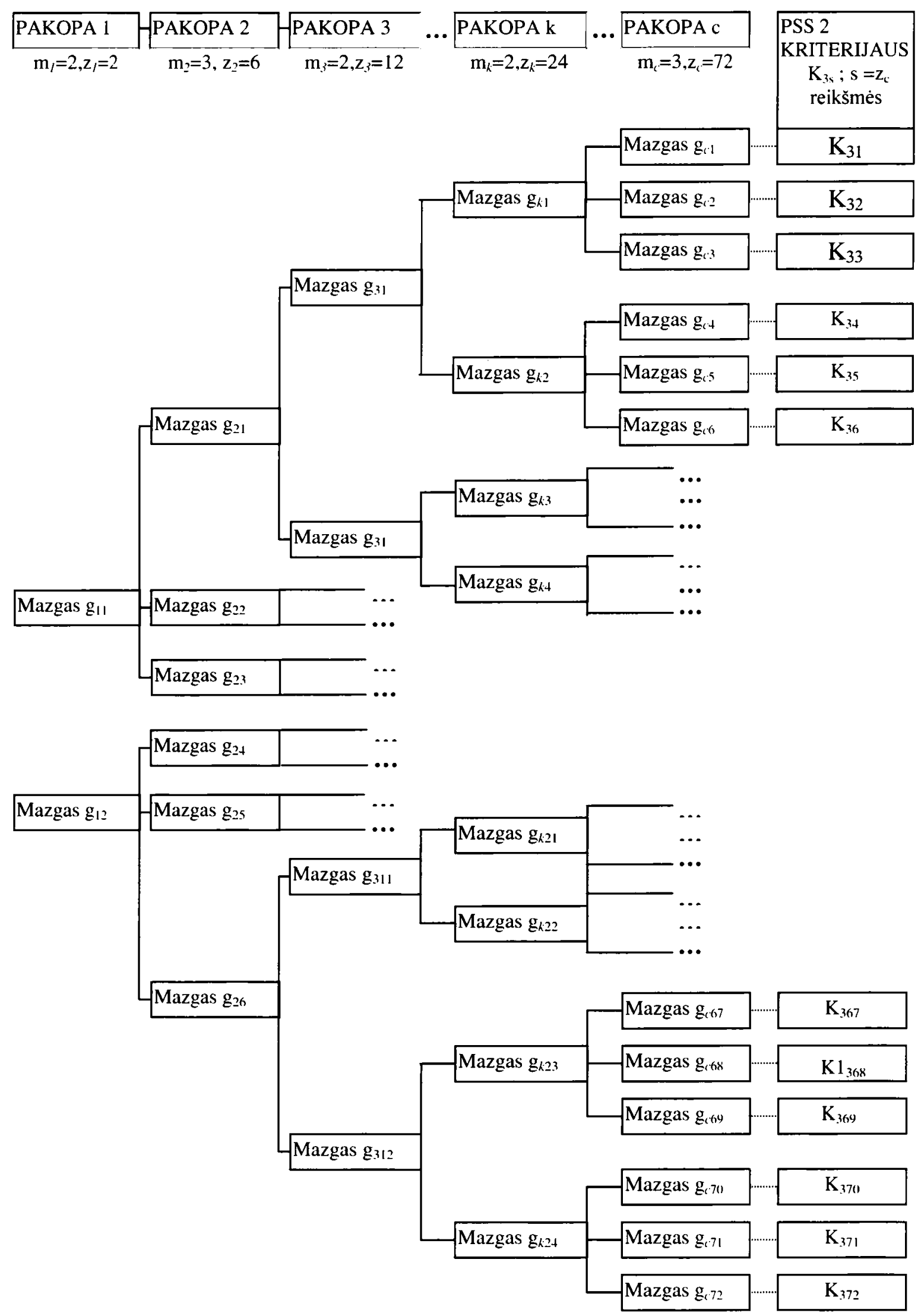

4 pav. DSS1 metodo sprendimy medžio (SM) struktūros fragmentas (pakopu skaičius c=5)

Fig 4. Fragment of decision tree formation structure with multicriteria project synthesis method DSSI 
To pakanka sprendimą atliekant vienos pakopos lygyje atskirai, kai yra nustatoma nagrinejjamų alternatyvu prioritetinè eilutè. Tačiau sintezuojant keliu pakopu alternatyvas, jungiant jas i bendrą vientisa uždavini. to nepakanka, nes cia jau reikia tikslumo nustatant alternatyvų reikšmingumo kriterijus. Dél to buvo ieškoma būdų, kaip nustatyti nagrinejjamu alternatyvu absoliučias tarpusavio reikšmingumo reikšmes. Atlikus skaičiuojamuosius eksperimentinius tyrimus buvo nustatyta, kad kiekvienoje $\mathrm{k}$ pakopoje atrinkus $m_{k}$ alternatyvas, prieš vykdant galutinę sprendimo sintezę reikia atlikti specialius skaičiavimus. Šiuo tikslu ir buvo pritaikytas siūlomas absoliutaus artumo idealiajam taškui metodas.

- Atlikus papildomus perskaičiavimus ir nustačius visų SM k-tosios pakopos $\mathrm{g}_{k, e}$ mazge paliekamų alternatyvu absoliučius tarpusavio ryšius $\mathrm{K}_{\text {bita, }}$ yra pereinama prie kitos $\mathrm{k}$ pakopos, kartu sintezuojant gretimų, prieš tai nuo 1 iki k nagrinètų pakopų mazgus. Sintezè jungiant nagrinejjamose pakopose paliktas alternatyvas i bendrus sprendinius, atliekama naudojantis ryšio lentelèmis, atsižvelgiant ị tai, kurios alternatyvos buvo išrinktos tame etape, taip pat derinant prieš tai buvusius etapus, jeigu tai yra ne I sprendimo etapas, t. y. kiekvienam paliktam mazgui (alternatyvai) per ryšių lenteles $R_{1 . d}$ yra generuojama $\mathrm{s}$ sprendimų šaka; čia $l=\overline{1, \mathrm{k}-1}$ ir $d=\overline{2, \mathrm{k}}$ yra generuojami numeriai pakopu, kurioms yra konkrečiai sudaryta ryšiụ lentelè, prijungiant kito etapo dvi geriausias alternatyvas automatiškai arba pagal naudotojo nurodytą paliekamą geriausių alternatyvų kiekị. Taip yra galutinai suformuojamas sprendimo medis (SM) (4 pav.).

- Galutinès, daugiakriterinių sprendimų sintezès DSSl metodo sprendimų prièmimo matricos $\mathrm{W}=\left[\mathrm{w}_{\mathrm{s}, \mathrm{k}}\right] . \forall \mathrm{sk} ; s=\overline{1, z_{\mathrm{c}}} \quad k=\overline{1, c}$, remiantis $\mathrm{SM}$, formavimas. Čia pagal SM šakas $s=\overline{1, \mathrm{z}_{\mathrm{c}}}$ yra suformuojama galutinè sprendimo prièmimo matrica [W]. Šios matricos kiekviena s eilutè atspindi sintezès metodu i bendrą sistemą sujungtu, iš $k=\overline{1, c}$ pakopose naginejjamu atskiru statybos procesu ar projektų racionaliausių alternatyvų sudarytą galutiniam sprendimui paruoštą sintezès variantą.

- Kiekvienai sprendimų atšakai $s=\overline{1, \mathrm{z}_{\mathrm{c}}}$ priimamo sprendimo sèkmès (PSS 2) kriterijaus $K_{3 s}$ nustatymas pagal formulę (3) [1]:

$$
K_{3 \mathrm{~s}}=\max \prod_{\mathrm{k}=1}^{\mathrm{c}} \mathrm{w}_{\mathrm{s}, \mathrm{k}} ; \forall \mathrm{sk} \quad s=\overline{1, \mathrm{z}_{\mathrm{c}}}, k=\overline{1, \mathrm{c}}
$$

čia s - sintezuojamų viso sprendimo medžio šakų skaičius. Atliekama variantų sintezé pagal $K_{3 s}$ kriterijų, kur laukiamas rezultatas $\left\{w_{s}\right\} \in W$.

- SM k-tosios pakopos g $g_{\text {k.e }}$ mazgo varianty iš nurodyto skaičiaus nagrinèjamos $k$-tosios pakopos $m_{k}$ geriausių alternatyvu. remiantis ryšių matrica $R_{\mathrm{l}, \mathrm{d}}$, sudarymas. Čia vyksta dviejų arba daugiau naudotojo nurodytų geriausių alternatyvų atranka. Ji vykdoma iš $\mathrm{i}$ alternatyvų $i=\overline{\mathrm{l} . \mathrm{m}}$; čia $\mathrm{m}$ yra k-tosios pakopos alternatyvu skaičius, pagal $j$ šias alternatyvas apibūdinančiu kriterijų $j=\overline{1, \mathrm{n}}$; čia n yra ktosios pakopos alternatyvas apibūdinačių kriteriju skaičius.

- Lyginamų s variantụ prioritetiškumo eilès $\left\{w_{s}\right\}$, remiantis (PSS 2) kriterijumi $K_{3 s}$, sudarymas. Remiantis salyga, kad geriausias variantas $w_{s}, s=\overline{1, z_{c}}$ yra tas, kurio kriterijaus $K_{3 s}$ reikšmè yra didžiausia, ir suskaičiuotomis $K_{3 s}$ reikšmėmis, yra sudaroma galutiné prioritetų eilute (4):

$\left\{w_{s}\right\}=\left\{w_{1} \succ w_{2} \succ w_{3} \succ \ldots \succ w_{s} \succ \ldots \succ w_{z_{c}}\right\}$,

čia $\mathbf{z}_{c}$ - šakų, variantu atliekant sintezę skaicius. Sprendimu medžio (SM) kiekvienos s atšakos priimamo sprendimo sèkmès $K_{3 s}$ kriterijaus medžio fragmentas parodytas (4 pav.)

\section{Išvados}

Apibendrinant aprašytą projektų sintezès, remiantis priimamo sprendimo sékmès (PSS2) kriterijumi, metoda. (DSS1) galima teigti, kad jis yra skirtas dideliems projektams, apibūdinamiems ịvairiais uždaviniais su skirtingomis rodiklių sistemomis bei alternatyvas aprašančiomis ryšio lentelèmis, ivertinti. Metodas yra nesudettingas ir sudarytas iš tokių pagrindinių elementų, tai:

- Bendros duomenų bazès struktūra (DBS). Ji yra pakankamai paprasta užpildyti ir naudoti, skaičiavimams atlikti. Kartu ši struktūra apima visą informacija, kurios reikia sprendimui priimti. atskiras sprendimo pakopas sudarančias alternatyvas. šias alternatyvas išreiškiančių rodiklių sistemas bei suderinamumo (ryšio) lentelių aprašymus ir duomenis, vykdant daugiapakopi sprendima.

- Pagalbiniai metodai atskiru nagrinèjamy sprendimo pakopu rodikliụ pradiniams reikšmingumams nusta- 
tyti. Galima taikyti ekspertinio [1,3], porinio palyginimo, entropijos, rodiklių reikšmingumo nustatymo pagal jų dydžių nuostoli [1] ir kitus metodus. Autoriai šiam tikslui prie DSS 1 metodo siūlo taikyti ekspertinio ar porinio palyginimo metodus. Abieju metodu taikymas skaičiavimams yra nesudètingas. Galbūt tik porinio palyginimo metodu atliekant sprendimą reikia pateikti kiek imanoma daugiau ekspertų ivertinimų. Tačiau šiuo atveju, turint daug duomeny ivertinimui, gaunamas labai patikimas rezultatas su rekomendacijomis, o tai ir yra pagrindinis tikslas sprendimą atliekant bet kokiu metodu.

- DSS1 metodui yra taikomas literatūros šaltiniuose $[1,2,4]$ plačiai aprašomas ir rekomenduojamas artumo idealiajam taškui metodas dèl šiuo metodu gaunamų patikimų rezultatų. Čia yra nustatomas alternatyvų santykinès tarpusavio reikšmingumo kriterijaus $\mathrm{K}_{\text {bit }}$ reikšmès. Dèl to rezultatai, gaunami taikant DSSI metodą, taip pat yra patikimi.

- Taikant DSSI metoda skaiciavimas yra atliekamas pakopomis, kurioms sujungti $\mathfrak{i}$ bendra sistemą yra naudojami teoriškai ir praktiškai išbandyti sprendimo elementai, tai yra sintezuojamų variantų priimamo sprendimo sèkmès (PSS 2) [1] kriteriju $K_{3 s}$ reikšmès.

- Atlikus DSS1 metodo kūrimo metu gaunamu rezultatu išsamią analizę, buvo ivvestas nagrinejamu alternatyvų absoliutaus tarpusavio reikšmingumo terminas. Tam tikslui buvo patobulintas artumo idealiajam taškui metodas ir sukurta šio metodo absoliutaus artumo idealiajam taškui modifikacija.

- Pritaikius daugiakriterinių sprendimų sintezès metodą (DSS1) praktikoje, buvo parinkti efektyviausi konstrukciniai elementai (pastato karkasas, stiklo pertvaros ir automatinès durys, védinimo ir kondicionavimo sistema, pastato fasado apdaila) ir statybos procesai (projektavimas ir rangovo parinkimas) 6 aukštų administraciniam pastatui Vilniuje.

\section{Literatūra}

1. E. K. Zavadskas. A. Kaklauskas. Pastatu sistemotechninis ivertinimas. Vilnius: Technika. 1996. $280 \mathrm{p}$.

2. C. L. Hawang, K Yoon: Multiple attribute decision making - methods and applications, a state-of-the-at surwey. Berlin: Springer Verlag, 1981.

3. Э. К. Завадскас. Системотехническая оценка технологических решений строительного производства. Ленинград: Стройиздат. 1991. 257 с.

4. K. Yoon and C. L. Hwang. TOPSIS (technique for order preference by similarity to ideal solution) - a multiple attribute decision making, $w$ : Multiple attribute decision mak- ing - methods and applications, a state-of-the-art surwey. Berlin: Springer Verlag. 1981, p. 128-140.

5. V. Šarka, L. Ustinovičius. E. K. Zavadskas. Projektų sintezė naudojant kompromiso kompensacinius modelius statyboje // Statyba, V t., Nr. 6, Vilnius: Technika, 1999, p. 374-385.

6. Э. К. Завадскас. Многоцелевая селектоновация технологических решений строительного производства (Георетические основы). Вильнюс. $1989.156 \mathrm{c}$.

\section{Iteikta 20000530}

\section{METHOD OF PROJECT MULTICRITERIA DECISION SYNTHESIS ON THE BASIS OF DECISION SUCCESS CRITERION}

\section{V. Šarka, E. K. Zavadskas, L. Ustinovičius}

\section{Summary}

Method of project multicriteria decision synthesis with decision success criterion is used for realisation of construction projects which require a proper analysis of constituent parts in close relationship of components. Scheme of this method is presented in Fig 3.

Multicriteria decision project may be divided into several interrelated building processes and smaller projects. On every level of the whole project, the decision of closeness to ideal solution method is made and. on the basis of the obtained results, several alternatives are chosen.

On every separate level, a number of alternatives is selected by the method user. It depends on complexity of the project and on requirements of interested parties.

At the last decision stage, there is performed a synthesis using the chosen alternatives and relying on their interrelations.

During decision process on the intermediate stages, having eliminated irrational alternatives, effective and precise results are achieved.

The developed multicriteria decision synthesis method is one of the elements of the newly created group of multicriteria decision methods.

Using this method algorithm, software is prepared that entirely manages the whole decision process from database filling to calculation and result processing.

Vaidotas SARKA. PhD student. Department of Building Technology and Management. Vilnius Gediminas Technical University (VGTU), Sauletekio al. II. LT-2040 Vilnius, Lithuania. E-mail:TVSA@Bite.lt

A graduate of Vilnius Technical University (1993). Author of 6 publications. Research interests: decision-support systems in construction, technology and organisation of building. computing technology, with the purpose of creating automated system - decision-support system, with integrated multicriteria synthesis methods, in construction.

Leonas USTINOVIČIUS. Doctor, Associate Professor. Department of Building Technology and Management. Vilnius Gediminas Technical University (VGTU). Sauletekio al. 11. LT-2040 Vilnius. Lithuania.E-mail: aldonal@st.vtu.lt

Research interests: multipurpose selectonovation in the construction of technological decisions. He is also interesed in automated systems, improvement of project quality. Author of 70 research articles. 